\title{
Queen Anne Commands: Clothing the Kettle Drummer to the Ordnance, 1705-1708
}

\begin{abstract}
By Pat Poppy
The account books of the Board of Ordnance in the National Archives list the provisions made to the Ordnance, including clothing, and offer a wonderful insight into uniform provided to the soldiers serving with this branch of the military at time of the War of the Spanish Succession. Through a series of accounts dating from 1706 to 1708 this paper demonstrates how one position under the control of the Board of Ordnance, that of the kettle drummer, was ostentatious in the extreme requiring ninety yards of gold lace. The article will relate his clothing to clothing provided to other soldiers, and show how his clothes reflected the high status of the kettle drummer.
\end{abstract}

Keywords: kettle drummer, military uniforms, War of the Spanish Succession, Board of Ordnance, price of clothing, eighteenth century

This paper is based on the account books of the Board of Ordnance in the National Archives. ${ }^{1}$ These accounts offer a wonderful insight into the provisions made to the Ordnance for guns, powder and equipment, including clothing and cloth purchased for clothing. Most of the accounts for clothing are for quantities for use in specific theatres of war: £228 7s. 6d. for 69 suits for service in Newfoundland and Portugal in September 1705, and a further £1,367 6s. 2d. for 380 suits for service in Holland and Catalonia in March 1705/6. The majority of these accounts are for suits consisting of a coat, waistcoat and breeches and the cost of them is not itemized. However, one man, the kettle drummer, has his wardrobe accounted for in detail. This paper will look at these accounts and relate them to clothing provided to other soldiers in the Ordnance, and show how his clothes reflected the status of the kettle drummer within the Ordnance.

This is the period of the War of the Spanish Succession (1702-1713) which was fought not only in Europe but also in North America, where it is known as Queen Anne's War. By this time most European armies had adopted standard uniform colours rather than each regiment being dressed in a different colour with each army needing a field sign to identify their own side in battle. Uniformity for national armies started with the indelta (conscripted) regiments of the army of King Gustavus Adolphus of Sweden in the 1630s. ${ }^{2}$ In the English Civil War the New Model Army, formed in 1645, was uniformed in red. As Arch has said, this became a brand, forming the basis of the red coat that remained the British army's trademark until the end of the nineteenth century. ${ }^{3}$ There were still exceptions to uniformity; foreign, elite and specialist units within an army often had a different uniform, so the Dutch army wore grey, but the Scots fighting for them wore red and the Walloons green. The French army was mainly in gris blanc (off white/light grey) but the Maison du Roi, the king's own regiments, were in blue. The Danish army were also in grey, but their artillery were in purple. Drummers within all these armies wore distinctive uniforms. ${ }^{4}$

In the early modern army two posts held an importance far beyond the rank of the holder; these were the ensign and the drummer. The reason for this is that, before the days of field telephones, walkie talkies, radios and mobile phones, these two posts were responsible for communication between the officers and the soldiers. Brigadier General Richard Kane (1662-1736), in his memoir of the war, wrote of the problem should an officer be killed in battle and the voice of command change: 'Whereas the drum is always the same and much easier heard and understood, [...] then the drum will be of the greatest consequence'. ${ }^{5}$ The ensign carried the colours, that is the standard or flag or, in the case of cavalry, the guidon. The drummers relayed the commands; they beat the advance, the retreat and the reform, and regiments would form upon their colours, 
the colours indicating to the men where to find their regiment on the battlefield. The drummers are therefore dressed differently from the ordinary soldier so they could easily be seen in the chaos of battle.

Strictly speaking, the Board of Ordnance, whose accounts these are, was not part of the army. The army, comprising the regiments of infantry and cavalry, came under the control of a CaptainGeneral. Until the mid-nineteenth century the Board of Ordnance had its own hierarchy which was completely separate. The Ordnance was originally responsible for the provision of artillery and munitions to the army and the navy for use in garrisons, on board ship or in war. The first Master of the Ordnance was appointed in 1414, and the remit of the Board from that date until 1683 had little to do with the use of the weapons, only their provision. That the Board of Ordnance had become involved in the provision of clothing to the army is shown as early as 1645. A surviving notebook from that date lists copies of contracts for coats, cassocks, breeches, stockings, and a vast number of shoes, among other items. ${ }^{6}$ In 1683 the Board became responsible for the use of the weapons and the soldiers that came with its provision of artillery and engineer trains to the army. ${ }^{7}$

At times of war the Board of Ordnance would form these trains, drawing together the required artillery (cannons, mortars, etc.) mounted on carriages with horses and drivers, as well as the engineers and their men for digging fortifications and, of course, the gunners. Also formed up were the people who supported all of these, including those who made repairs to the equipment: wheelwrights, coopers, farriers and the like, some of whom, such as the wagon drivers, were civilians. To give an idea of the scale, the train for the Siege of Lille in 1708 contained a hundred guns, sixty mortars, three thousand wagons and fi fteen thousand horses. ${ }^{8}$ The organizational structure under the Board of Ordnance was very different to the regimental structure within the infantry of the army. Traditionally the artillery did not have physical colours and regarded its guns as its colours; it did, however, have drummers. Within the army there was a hierarchy among drummers; there was, for example, a certain status to being allowed to use kettle drums. Kettle drums were often much larger than the ordinary drum that was carried by the drummers of foot regiments, and they were unlike the straightsided drums that the infantry used being hemispherical, often of copper or brass, with a membrane stretched over the top. The banners, which hung from the top edge of the drum, would have been embroidered with the royal coat of arms, and these appear in the kettle drummer accounts. From the restoration of Charles II in 1660 kettle drums were only allowed to be used by the Life Guards. In 1689 the privilege of using kettle drums was extended to the Master General of Ordnance who was allowed a pair of kettle drums to be mounted on a carriage drawn by four white horses. ${ }^{9}$ A later painting, by David Morier, of the kettle drummer, his driver and carriage near the River Roer at the time of the War of the Austrian Succession appears as Figure 1. This painting possibly dates to around 1748 as this was the last time the artillery kettle drums appeared in the field. ${ }^{10}$

Three accounts for outfitting the Ordnance kettle drummer and his driver exist in the account books, and all are paid to a lady called Mary Hunter of whom we know nothing. She may have been chosen because she was an embroiderer, and the work involved in embroidering and making up the kettle drum banners was beyond the scope of those supplying the ordnance with ordinary uniforms. A 1702 description lists the drum banners as 'each with Her Majesty's arms richly embroidered on the finest Genoa damask of proper colours with fringes and tassels and cases of good oyle cloth' ${ }^{11}$ The first account is paid in March 1704/5 and is for the kettle drum banners and the outfit for the kettle drummer and amounts to $£ 1099 \mathrm{~s} .^{12}$ The second, for $£ 5717 \mathrm{~s}$., specifying that it is for the kettle drummer with the Holland Train, is from a warrant dated 26 February 1705/6 and paid on 13 April 1706, which gives the impression that the complete commission took seven weeks to make. ${ }^{13}$ 
The third account is for the drummers for the Flanders Train where the warrant is dated 22 November 1707 and was paid on 19 March 1707/8. It is for the drum banners, the kettle drummer, the driver and three other drummers, and comes to a total of $£ 10510 s^{14}$ In two of the accounts, the first and the last which took longer to complete, the bills include $£ 66$ for embroidering and making up the kettle drum banners. To put this sum into perspective, Richard Hart, who provided two new 'heads' or membranes for the kettle drums in 1708, charged $£ 1$ 16s. $0 d$. for the new heads and 20s. for an ordinary drum and its drumsticks. ${ }^{15}$

Mary Hunter provides the drummers and their drivers with both a standard suit, consisting of a coat, waistcoat and breeches, and also stockings, shoes, hats and gloves. At this period the clothing to be provided for a soldier was not set down, although work was being done on what should be provided. In 1703 instructions were issued which stated that 'the General [then John Churchill (1650-1722), soon to be made Duke of Marlborough] having approved and sealed the patterns for clothing, the Colonels are to contract for its supply and exhibit to the Controllers the contracts, which must specify the qualities, quantities and prices of each particular' ${ }^{16}$ From this it can be deduced that, although the colonels of individual regiments still had a considerable amount of control over what was being supplied to the soldiers under their command, much is being centrally dictated. By the year of the final account, 1708, the clothing to be provided for an infantry man had become specified by the Board of General Offi cers which had been convened by John Churchill. At this time, uniquely, Churchill held both the post of Captain General of the Army and that of Master of the Ordnance which meant that the two separate organizations were working with a degree of coordination. The Board of General Officers declared that a soldier should receive:

1st year a good full bod'd cloth coat well lined which may serve for a waistcoat the 2nd year, a waistcoat, a pair of good kersey breeches, a pair of good stockings, pair of good shoes, 2 shirts and neckcloths, good strong hat well laced. 2nd year: a good cloth coat lined as first year, waistcoat made of from 1st year's coat, Pr of strong new kersey breeches, pr of good strong stockings, pr of strong shoes, a good shirt and neck cloth and a good strong hat well laced. ${ }^{17}$

It would appear therefore that Mary Hunter is providing everything except the linens, which are the shirts and neckcloths, and also providing gloves as an additional item. In this respect she is unusual.

The clothing provided to the kettle drummer is in the colours used by the artillery at that time. The artillery in this period, right at the beginning of the eighteenth century and prior to the formation of the Royal Artillery in 1716, wore a red coat. After 1716 the artillery, distinctively for the British army, wore blue coats. ${ }^{18}$

The Morier painting shows the drummer and his entourage still wearing red coats, and this distinguishes them from the artillery men and officers around them who wear the later blue coat. The cloth that made the body of the red coat is only one part of the uniform, and the additions to it changed depending on the regiment and its colonel, so that those in the know could instantly recognize which regiment a soldier was from by what he was wearing. For the artillery and its drummers, the uniform in the accounts was a red coat lined with blue so that the turnbacks of the cuffs were also blue. The coat was accompanied by a blue waistcoat and blue breeches. The combination of colours, for coat lining, breeches and stockings, defines the regiment, and occasionally this comes through within a regiment's name. In the infantry, in the first half of the eighteenth century, regiments were usually referred to by the name of their current colonel. At one point in the 1740s there were two regiments with colonels named Howard. One of these regiments had green linings and therefore green cuffs and facings, and so it became known as the Green Howards, a name which has continued to modern times. ${ }^{19}$ It was rare for a colonel's influence on the detail of his regiment's clothing to be overridden by a general decree, although 
the death of Queen Anne's husband, George of Denmark, late in 1708 resulted in Churchill issuing an order that 'Colonels [. . .] are to give directions [. . .] to have red coats with black buttons and button holes for their respective regiments clothing for the present year'. ${ }^{20}$ It had become a tradition that the army wear black buttons at times of mourning. This dated back to the death of Oliver Cromwell in 1658 when at his funeral it was stated that 'souldiers [wore] new red coats and black buttons'. ${ }^{21}$

It has been noted that Mary Hunter was unusual in providing everything except the linens for the drummers. It was more common for specialist providers to be used, so Ambrose Wilson, described as a 'haberdasher of hatts', provides the Ordnance with 179 hats laced with yellow and forty-eight plain hats for the sum of $£ 39$ 14s. 6d., while Daniel Franklyn and William Grimes, beltmakers, provide 1,000 waist belts of neat's leather for $£ 8710 \mathrm{~s}$. $0 \mathrm{~d}^{22}$ Neat indicates that the leather is cow or ox hide. ${ }^{23}$ Suits were provided by another contractor for the Ordnance, William Pate. Pate was a woollen draper who inherited his business from his father in the 1690s. He was known as the Learned Tradesman because of his friendship with men such as the essayist Jonathan Swift (1667-1745) and the poet Alexander Pope (1688-1744). ${ }^{24}$

Pate provides mainly suits, consisting of a coat, waistcoat and breeches, though sometimes he provides just coats. The type of suit provided by Pate is shown in Figure 2, which is a tapestry at Blenheim Palace depicting the Battle of Wynendael, 28 September 1708. The tapestry is one of a series commissioned by Marlborough, and it was being woven by November $1711 .^{25}$ The soldier on the left, carrying a spontoon, is a sergeant, the man on the right, with a musket, is an ordinary soldier, the waggoner on horseback, while technically a civilian, would have been provided with at least his coat. The sergeant can be seen to have left the top of his coat unfastened and turned back showing his waistcoat underneath, this was the start of a military fashion that lasted for the next hundred years. Both the sergeant and musketeer wear the cocked hats and leather waist belts mentioned above as being provided. A payment to Pate from 1705 lists: ${ }^{26}$

To William Pate ye sum of Two hundred twenty eight pounds seven shillings and six pence for ye clothing undermentioned for ye service of Newfoundland and Portugal 2 warrants dated 7th July and 20th September $1705 \mathrm{viz}$

Coats, waistcoats \& breeches for -

Master gunner 1 suite

Gunners 14 att £3.2s.10d each

Mastr Artifficers 4 at $£ 4.12$ s.2d. ea

Fireworker 1 att

Serjeants 3 att $£ 4.12$ s.2d

Coller maker 1 att

Drummers 2 at $£ 4.12 \mathrm{~s} .2 \mathrm{~d}$ ea

Matrosses 40 at $£ 2.19$ s.10d ea

Miners 3 att $£ 3.2 .10 d$ ea 986

\section{$£$}

4

43

18

4

13

4

9

119

228

$\begin{array}{rl}\mathrm{s} & \mathrm{d} \\ 12 & 2 \\ & \\ 19 & 7 \\ & \\ 8 & 8 \\ 12 & 2 \\ 6 & 6 \\ 12 & 2 \\ 4 & 4 \\ 13 & 4 \\ 7 & 6\end{array}$

The cheapest suits therefore are provided for the lowest ranks. Suits for the matrosses, the men who serve on the guns, come out at $£ 219$ s. 10d. each, and above them are the miners, who tunnel under walls and fortifications in order to blow them up, and the ordinary gunners, who command the individual guns, both of whose suits come out at $£ 32$ s. $10 \mathrm{~d}$. each. Above all these are the craftsmen and specialists who have suits at $£ 412 s$. $2 d$. These people include trades that appear in the general population, such as the collar maker for the horses' harness and, in other of Pate's bills, coopers, carpenters, wheelwrights and smiths. But there are also those who are specialists 
within the army and here we find fireworkers, master gunners and master artificers. Noncommissioned officers, such as sergeants, have suits that cost $£ 412$ s. $2 d$. The ordinary drummers in this bill also have suits costing $£ 412 \mathrm{~s}$. $2 d$. which is just over half the price of the more expensive kettle drummer's suit. The accounts for the kettle drummer go into much more detail and show that even in their basic form, without the addition of braid, the drummer's and driver's suits are more expensive than those for other ranks in the artillery trains, including those drummers not related to the kettle drummer's entourage. The 1704/5 drummer's suit costs $£ 818$ s. $0 d$., a 1706 driver's suit was $£ 65 s$. 3d., and a 1708 kettle drummer’s suit was $£ 718$ s. $3 d$. As can be seen, these prices are much higher than even the master gunners and sergeants.

Whereas the Pate bills just give a general price for the whole suit, Mary Hunter's bills are far more specific, breaking the sums down into the cost and types of cloth, the notions and the cost of making. The coat, sometimes referred to in the accounts as a surtout, is usually made of threeand-a half yards of scarlet cloth at 15s., $16 s$.or $£ 12 s$. $0 d$. a yard. It is then lined with four-and-ahalf yards of serge at 2s. $2 d$.a yard, presumably a narrower fabric than the scarlet cloth. This fits with the requirement for a full-bodied coat well lined. These fabric amounts, together with illustrations of ordinary soldiers of the time, such as appear in the Wynendael tapestry of 1708 (Figure 2), would seem to indicate that the coats followed the fashion for wide skirts to the coat with pleats set at the side seams and a narrower pleat at the back seam. This tailoring can be seen in patterns taken by Norah Waugh from fashionable early eighteenth-century coats, and there was no attempt to skimp on material. ${ }^{27}$ The coats of drummers are considerably more decorated than those of other soldiers. Although some soldiers' uniforms did have some braid, this was mainly to distinguish rank and on nothing like the scale of the kettle drummer uniform. The prices above are the cost of the drummer's coat before the addition of the lace or braid that decorates the coats. A 1697 description of how the lace was applied states there should be

Two bands of lace down the front with buttonhole loops between, down all seams of sleeves, shoulders, back the skirt openings and round the bottom [. . . ] a lace at the back of the waist and two round the edges of the cuffs. The sleeves have six laces running around horizontally. Beside all this 'ten laces on the body and round each side' And there is further indication that a narrow lace is placed between the broad. ${ }^{28}$

In two of the accounts Mary Hunter lists this lace. In the 1706 account there are 50 yards of velvet lace at 1 s. $6 d$. per yard plus 12 yards of narrow velvet lace at 1 s.per yard, while the 1704/5 account has 50 yards of broad gold lace at 7s. per yard, 30 yards of narrow gold open at 2s. $6 d$. per yard, and 10 yards of narrow gold binding at 3 s. per yard. This means that in the 1704/5 account the lace alone costs $£ 22$ 15s., and this is followed by the comment 'for the addition to the gold lace \& fringe for the kettle drums more than last time $£ 3$ '. ${ }^{29}$ The kettle drummer's driver is far less heavily decorated, having two gold laces down the front and around all openings, seams and sleeves, and this difference continued as can be seen in the later Morier painting. The suit is completed by the addition of a blue waistcoat and breeches made from ' $23 / 4$ yards of blue cloth at $12 \mathrm{~s}$ a yard', with a further 15s. for 'lineing for ye wastecoat, breeches and pockets' and 'for making, silk thread \& ca' 7s 6d'. The

cost for the waistcoat and breeches is therefore $£ 213 s$. $0 d$., nearly the price of an entire suit for a matross. The buttons used on the suit are not always specified, the 1707/8 account listing ' $31 / 2$ dozn of buttons at $5 \mathrm{~s}$ a dozn' giving at total of $17 \mathrm{~s}$. $6 \mathrm{~d}$., and then for the other drummers simply 'gilt buttons' for the same amount. The 1705/6 account has gilt buttons listed at 5s. a dozen, but the 1704/5 account has gold buttons at 10s. a dozen. It is difficult to work out precisely how many buttons are involved as sometimes an unspecified number are listed under the coat and then a further $3 \frac{1}{2}$ dozen under the waistcoat and breeches. The coat has buttons on the cuffs and the pocket flaps as well as down the front, and the waistcoat has buttons making a tight closure at the end of the sleeve and on the pockets as well as down the front. In addition to the suit, Mary 
Hunter provides a pair of shoes and stockings for a further 10s. $6 d$., and a laced hat and gloves for $£ 1$. It would appear from Ambrose Wilson's account that hats averaged out at about 3s. 6d. each, and Spufford has shown that gloves were relatively cheap, running at between $2 d$. and 3s. a pair, so it would appear that Mary was charging over the odds. ${ }^{30}$

Soldiers were expected to pay for their uniforms out of their wages. There was a very complicated system whereby, at the beginning of the War of the Spanish Succession, ordinary soldiers were paid $£ 1213 s$. $4 d$. a year from which $£ 910$ s. was deducted for subsistence. Much of the remaining amount, known as 'off reckonings', was taken over by the colonel for the provision of uniform and arms.

A day’s pay went to the Chelsea Hospital. Since a matross’s suit cost $£ 219$ s. 10d., the remaining sum of $£ 3$ must have been insufficient unless the officer added additional money. A report in 1702 brought about the dismissal of the Paymaster-General for misappropriation of public funds, and Churchill reorganized the system insisting that the costs of 'the clothing does not exceed in cost of off reckonings' ${ }^{31}$ The minutes of the meeting in February 1705/6, which set the clothing for the foot regiments, indicates that the offi cers were well aware of the problems for they state, 'And as the Genll Officers before appointed are directed to regulate the Cloathing according to the circumstances of the Regiment being in Debt or not, so they are likewise to have regard to the natures of the Payments'. They also express a hope that the new method of providing clothing will 'effectually prevent any future dispute and take away all season of Complaint'. ${ }^{32}$

It is difficult to see how a kettle drummer could ever have paid for his uniform, even though his pay was three times that of a matross. The drummer that accompanied the 1702 artillery train to Holland was paid 3s. a day and his driver 1 s. 6 d., while the $1704 / 5$ suit cost $£ 818$ s. $0 d$., nearly three times that of the matross’s suit, and the braid was an additional £22 15s. 0d.33 In a foot regiment the extra might

have been covered by the colonel, but the organization in the Ordnance is different and it would appear that the Board bore the cost.

Little is known of the Ordnance kettle drummers themselves. The first whose names are given are those that accompanied an artillery train to Flanders in 1693 when the drummer was a John Burnett and his driver was John Humphries. ${ }^{34}$ It is interesting to wonder what the kettle drummer might have thought about wearing an outfit that cost more than his entire annual income.

\section{Acknowledgements}

My thanks go to the brothers Paul and Kendall Leask who, while researching the equipping of Marlborough's army, brought these accounts to my attention.

1 The National Archives, WO 51.

2 Anthony Kemp, Weapons and Equipment of the Marlborough Wars (Poole: Blandford Press, 1980), p. 139.

3 Nigel Arch, 'The Wearing of the Red: The Redcoat and the British Brand', Costume, 41 (2007), 99-105.

4 C. S. Grant, The Armies and Uniforms of Marlborough's Wars (Leigh-on-Sea: Partizan Press, 2004), pp. 37-60.

5 Brigadier General Richard Kane, Campaigns of King William and Queen Anne from 1689 to 1712 (London: Millan, 1745; facsimile Uckfi eld: Naval and Military Press), pp. 115-16.

6 Gerald Mungeam, 'Contracts for the Supply of Equipment to the New Model Army in 1645', Journal of the Arms and Armour Society, 6 (1968), 53-115.

7 The National Archives. Ordnance: Records of the Board of Ordnance <http://www.nationalarchives.gov.uk/ records/research-guides/board-of-ordnance.htm> [accessed 9 January 2011].

8 P. H. Smitherman, Uniforms of the Royal Artillery, 1716-1966 (London: Hugh Evelyn, 1966).

9 Hugh Barty-King, The Drum (London: The Royal Tournament, 1988), pp. 38-39.

10 Barty-King, The Drum, p. 71.

11 Cecil C. P. Lawson, A History of the Uniforms of the British Army, vol. I, From the Beginnings to 1760 (London:

Kaye and Ward, 1940), p. 178.

12 The National Archives, WO 51/69, 31. 
13 The National Archives, WO 51/70, 58.

14 The National Archives, WO 51/74.

15 The National Archives, WO 48/48, 17 August 1708.

16 The National Archives, WO 46/6.

17 The National Archives, WO 26/13, 45-47.

18 Smitherman, Uniforms of the Royal Artillery, 1716-1966.

19 Green Howards Museum, History of the Green Howards <http://www.greenhowards.org.uk/reghistory.php?> [accessed 15 March 2011].

20 Lawson, Uniforms of the British Army, p. 16.

21 James Heath’s Chronicle, 1676, cited in Phillis Cunnington and Catherine Lucas, Costume for Births,

Marriages and Deaths (London: Black, 1972), p. 231.

22 The National Archives, WO 48/48, 25 May 1708 (hats), 27 May 1708 (belts).

23 Oxford English Dictionary online, 3rd edn, June 2003; online version March $2011<$ http://www.oed.com:80/

Entry/125561> [accessed 13 June 2011].

24 Thomas Seccombe, and Philip Carter, 'William Pate', in The Dictionary of National Biography<www.

oxforddnb.com> [accessed 4 February 2010].

25 Jeri Bapasola, Threads of History: The Tapestries at Blenheim Palace (Lydney: Lightmoor Press, 2005).

26 The National Archives, WO 51/67.

27 Norah Waugh, The Cut of Men's Clothes 1600-1900 (London: Faber, 1964), pp. 62-65.

28 Lawson, Uniforms of the British Army, p. 170.

29 The National Archives, WO 51/69, 31; WO 51/70, 58; WO 51/74.

30 Margaret Spufford, The Great Reclothing of Rural England (London: The Hambledon Press, 1984), p. 100, 198

and 221.

31 Lawson, Uniforms of the British Army, pp. 43-46.

32 The National Archives, WO 26/13, 45-47.

33 Barty-King, The Drum, p. 39.

34 Barty-King, The Drum, p. 39.

\section{APPENDIX \\ THE THREE ACCOUNTS TO MARY HUNTER FOR THE KETTLE DRUMMER}

\section{WO 51/69, 31}

15 March 1704

To Mary Hunter the sum of one hundred and five pounds for the work the following for the kettle drums and drummer

For Imbroidering the kettle drums $\quad £ 66$

For 2 p(air) of tassels $\quad £ 1 \quad 10$ s

For the kettle drummer

For Imbroidering 2 crowns and ciphers $\quad £ 6$

$31 \frac{12}{2}$ yd of scarlet cloth at £1-2s-0d p yd $\quad £ 3 \quad 17 \mathrm{~s} \quad$ 0d

for lining the coat

3 dozn of gold buttons at 10s a dozen $\quad £ 1 \quad 10$ s

for making the coat, coat, \&c $\quad £ 2 \quad 15 \mathrm{~s}$

for stockings $6 \mathrm{~s}$

for laced hat and gloves $\quad £ 1$

50yds broad gold lace at 7s p yd $\quad £ 17 \quad 10$ s

30yds narrow do open at 2s 6d p yd $\quad £ 3 \quad 15$ s

10yds narrow do binding at 3s p yd $\quad £ 1 \quad 10$ s

for the addition to the gold lace \& fringe for the kettle $\quad £$

drums more than last time 
by order of the board

29th March 1705

Atto 29th March 1705

NB the original does say 'One hundred and five pounds' in words and £109 in figures

WO 51/70, 58

To Mary Hunter ye sum of fifty seven pounds seventeen shillings for the particulars following being for the drummers belonging to the Holland trayne \& warrant dated 26 February $1705 \mathrm{Viz}$ Coats laced 3 Att several prices Undermentioned amounting to $£ 5717$ s 0d

Atto 13th April 1706

Cloth wastecoats 3

Breeches $3 \mathrm{p}$

Crimson surtout coat 1

Cloth waistcoat 1

Breeches $1 \mathrm{p}$

Crimson surtout coat 1

Shoes $4 \mathrm{p}$

Stockings $4 \mathrm{p}$

Gloves $4 \mathrm{p}$

Hatts laced 4

For ye kettle drummer

$3 \frac{1}{2}$ yards of scarlett cloth for a surtout at 15 s per yd

$4 \frac{1}{2}$ yds of serge to line it at $2 \mathrm{~s} 2 \mathrm{~d}$ per yard

$£ 2 \quad 12 \mathrm{~s} \quad 6 \mathrm{~d}$

Buttons, silke \&ca

makeing

For the driver

$3 \frac{1}{2}$ yards of scarlett cloth for ye surtout at 15 s a yd

$4 \frac{1}{2}$ yds of serge to line it at $2 \mathrm{~s} 2 \mathrm{~d}$ a yard

Buttons, silke \&ca

makeing

$23 / 4$ yds blew cloth for waistcoat and breeches at $12 \mathrm{~d}$

For lining ye coat and waistcoat

For a drummer

$31 / 4$ yards of scarlett cloth for ye coat at $16 \mathrm{~s}$ a yd

$23 / 4$ yds of do blew for wastecoat $\&$ breeches at 12 s a yard

Lineing for ye coat and wastecoat

for lineing and pockets for ye breeches

$3 \frac{1}{2}$ dozn of Gilt buttons at 5 s per dozn

50 yds of velvet lace at $1 \mathrm{~s} 6 \mathrm{~d}$ per yd 
making the suit

a pr of stockings, shoes, hatts \& gloves

1

Two more drummers suits all ye same as this at $£ 1415$ s $6 \mathrm{~d}$ ea $\quad 29$

$29 \quad 11$

A box to put the suits in

5

A cord

Pd ye porter for carrying ye box to the Tower

$\begin{array}{lll} & & 6 \\ 57 & 1 & 6\end{array}$

\section{WO 51/74}

19th March 1707

To Mary Hunter the sum of one hundred pounds for the particulars hereafter mentioned being for the drummers \&c belonging to the Flanders Traine - Warrant dated the 22nd Novemr 1707

For the kettle drummer

$31 / 2$ yards of scarlett cloth for ye surtout at $15 \mathrm{~s}$ a yd

$2 \quad 12 \quad 6$

$4 \frac{1}{2}$ yds of serge to line it at $2 \mathrm{~s} 2 \mathrm{~d}$ a yard

99

Buttons, silke \&ca

makeing

$23 / 4$ yards blew cloth for his wastecoat and breeches at $12 \mathrm{~s}$

$1 \quad 13$

Lineing for ye wastecoat, breeches and pockets

$3 \frac{1}{2}$ dozn of buttons at $5 \mathrm{~s}$ a dozn

for making, silk thread \& ca

a pr of shoes and stockings

$18 \quad 3$

a laced hatt and gloves

For the driver

$3 \frac{1}{2}$ yards of scarlett cloth for ye surtout at 15 s a yd

makeing

a pr of shoes and stockings

10

for a laced hatt and gloves

For a drummer

$3 \frac{1}{4}$ yards of scarlett cloth for ye coat at 16 s a yd

Lineing for ye coat and wastecoat

Gilt buttons

making the suit

a pr of stockings, shoes, hatts \& gloves

For 2 other drummers

suits as above at $£ 8-4 s-6 \mathrm{~d}$ a suite 


\section{Three accounts to William Pate for the provision of other clothing to the Ordnance}

\section{3rd March 1704}

To William Pate ye sum of Five hundred forty eight pounds seven shillings and six pence for ye Coats undermentioned for ye service of the Holland Trayne of War 27th Feb 1704/5 viz

Surtout coats for Gunners 90 at $£ 2$ 18s $9 d$ ea

Matrosses 142 at $£ 2$ ea

$\begin{array}{lll}264 & 7 & 6 \\ 284 & & \\ £ 548 & 7 & 6\end{array}$

Atto 24 March 1704

\section{9th September 1705}

To William Pate ye sum of Two hundred twenty eight pounds seven shillings and six pence for ye clothing under mentioned for ye service of Newfoundland and Portugal 2 warrants dated 7th July and 20th September 1705

Master gunner 1 suite

Gunners 14 att £3.2s.10d each

Mastr Artifficers 4 at $£ 4.12$ s.2d. ea

Fireworker 1 att

Serjeants 3 att $£ 4.12$ s.2d

Coller maker 1 att

Drummers 2 at $£ 4.12 \mathrm{~s} .2 \mathrm{~d}$ ea

Matrosses 40 at $£ 2.19 \mathrm{~s} .10 \mathrm{~d}$ ea

Miners 3 att £3.2.10d ea

$\begin{array}{lll}4 & 12 & 2 \\ 43 & 19 & 7 \\ 18 & 8 & 8 \\ 4 & 12 & 2 \\ 13 & 6 & 6 \\ 4 & 12 & 2 \\ 9 & 4 & 4 \\ 119 & 13 & 4 \\ 9 & 8 & 6 \\ £ 228 & 7 & 6\end{array}$

\section{8th March 1705}

\section{Atto 9th May 1706}

To Willm Pate ye sum of One thousand three hundred and sixty seven pounds six shills \& two pence for ye clothing under mentioned being for the trayne in Catalonia and Holland 2 warrants bearing date 5th Jany \& 26th Febry 1705 viz

\begin{tabular}{|l|l|l|l|}
\hline Coats for & $£$ & s & d \\
\hline Master artifficers 6 at £2.18s.9d ea & 17 & 12 & 6 \\
\hline Coats, wastcoats \& breeches for & & & \\
\hline Artiffices 16 att £4.12s.2d & 73 & 14 & 8 \\
\hline Bombadiers 8 att £3.17s.4d ea $\}$ & & & \\
\hline Serjeants 8 att £3.17s.4d ea \} & 92 & 16 & \\
\hline Corporalls 8 att £3.17s.4d ea \} & & & \\
\hline Gunners \& 228 viz 96 at £3.17s.4d ea & 371 & 4 & \\
\hline Matrosses 132 at £2.19s.10d ea & 394 & 18 & \\
\hline Surtout coats for & & & \\
\hline Conductors 10- £4.12s.2d & 46 & 1 & 8 \\
\hline Coats, wastcoats \& breeches for & & & \\
\hline Gunners, matrosses \& ea 100 viz & & & \\
\hline Serjeants 3 att £4.12s.2d & & & \\
\hline Corporalls 3 att £4.12s.2d & & & \\
\hline Fireworker 3 att £4.12s.2d. ea & & & \\
\hline Bombadiers 12 att £4.12s.2d. ea & & & \\
\hline Conductor 6 att £4.12s.2d. ea & & & \\
\hline Coller makers 2 att £4.12s.2d. ea & & & \\
\hline
\end{tabular}




\begin{tabular}{|l|l|l|l|}
\hline & 193 & 11 & \\
\hline Smiths 2 att £4.12s.2d. ea & & & \\
\hline Wheelwrights 4 att £4.12s.2d. ea & & & \\
\hline Carpenters 5 att £4.12s.2d. ea & & & \\
\hline Coopers 2 att £4.12s.2d. ea & & & \\
\hline Gunners 16 att £3.2.10d ea & & & \\
\hline & 81 & 13 & 8 \\
\hline Miners 10 att £3.2.10d ea & & & \\
\hline Matrosses 32 at £2.19s.10d ea & & & \\
\hline & 95 & 14 & 8 \\
\hline & 1367 & 6 & 2 \\
\hline
\end{tabular}

Atto 9th May 1706

Pat Poppy is a university librarian and an independent dress historian. She has an MA in Early Modern English History, and her interests are particularly in the occupational, military and working-class clothing of the early modern period. 